\title{
Service Quality Management in Retailing: Theory and Empirical Analysis of Customer Satisfaction with Checkout Services
}

\author{
Mitsunori Hirogaki, Member, IEDRC
}

\begin{abstract}
This study aims to clarify the service attributes that are important to the customer at a supermarket checkout, and the levels of service attributes that are the most desirable from the customer's perspective. In this study, using a questionnaire survey on checkout services for a shopping supermarket chain and using conjoint analysis, the checkout services attributes and levels to which customers attach importance were analyzed. The participants included 415 customers in and around the Tokyo metropolitan area, of which 163 were men and 252 were women. The results show that the expected waiting time is the most influential factor in consumer satisfaction. In particular, the presence of three or more customers already in line is found to significantly reduce customer satisfaction. It was also found that the customer service attitude of employees is an important attribute to the customer. Interestingly, for the bagging services, it is found that it can have a negative impact on consumer satisfaction. On the other hand, the gender and age demographics of an employee have little effect on consumer satisfaction. These results not only give new implications for research but also are useful in practical terms, such as conducting employee training to identify improved ways to serve customers better and guide improvements in the operation of retail stores.
\end{abstract}

Index Terms-Checkout service, conjoint analysis, customer satisfaction, service quality management, supermarket.

\section{INTRODUCTION}

Customer satisfaction has been identified as a key performance indicator in service industries. It appears to be the primary link between today's operating decisions by the firm management and future consumer behavior toward the firm, i.e., in terms of future sales [1]. A satisfied customer becomes a loyal customer, generating repeat sales and favorable word-of-mouth advertising for prospective customers [1].

Researchers and retailers have recognized the importance of providing a high level of service to customers [2], [3]. The management should focus on gaining customer loyalty by enhancing customer perceptions of service quality and increasing the perceived consumer value [4].

For many sectors of the hospitality industry, e.g., tourism and hotels, improvement in service quality provided to customers continues to be an important issue to the

Manuscript received December 10, 2013; revised March 31, 2014. This research was supported by a Grant-in-Aid for Young Scientists (B) (No. 23730424) from the Ministry of Education, Culture, Sports, Science, and Technology of the Japanese Government.

M. Hirogaki is with the Faculty of Economics, Kushiro Public University of Economics, Ashino 4-1-1, Kushiro City, Hokkaido 085-8585, Japan (tel +8537 5519, e-mail: hirogaki@kushiro-pu.ac.jp). management. This is because it has a direct impact on customer satisfaction [5]-[7].

For the service sector, the management of service quality is considered to be an important issue in the retail industry. The level of customer service has been observed to significantly influence store loyalty and customer satisfaction [8].

While aiming to enhance service levels, it is necessary for retailers to minimize the corresponding increases in operating costs. In particular, the development of technology has caused the number of companies adopting automation of clearing services to increase [9], [10]. However, in Japan many consumers tend to focus on the level of customer service. The slow spread of self-checkout may be seen as evidence of this focus [11]. Japanese consumers tend to regard store cash register services as an important evaluation element of customer service [12].

This study aims to clarify the service attributes that are important to the customer at checkout in a supermarket, and to ascertain the levels of service attributes that are the most desirable from the customer's perspective.

This study is organized as follows. Section II reviews previous research and constructs hypotheses regarding checkout service. Section III presents the study methodology. Section IV describes the corrected data. Section V presents conceptual models. Section VI presents the results of the analysis. Section VII discusses the findings of the empirical analysis, and Section VIII concludes.

\section{PREVIOUS RESEARCH}

This section reviews previous studies on customer satisfaction with shopping and checkout experiences, and develops conceptual hypotheses for this empirical study.

Employees providing checkout service in retail stores, e.g., supermarkets, bookstores, and grocery stores, are still predominantly female. Some service industries are traditionally dominated by either male or female frontline service staff [13].

There exist empirical and theoretical analyses on the effect of the server's gender on their interpretation of customer service [14], [15]. Reference [14] shows gender differences in the behavior of service employees. In addition, customers may expect, and respond better to, frontline service staff of the "right" gender. Existing research has investigated the extent of the influence of the server's gender, and the gender dyad between customer and server, on perceived service quality and customer satisfaction [16], [17]. According to [15], retail staff have different interpretations of customer service. In addition, the effects of outcome favorability, 
opportunity to respond, and demographic congruence on customer reactions to bank loan decisions were investigated [18].

In previous interviews of consumers and people working in human resources in supermarket chains, the subjects argued that customers sometimes prefer older female employees, as their perceived service level is high and they are friendly to customers.

On this basis, the following hypotheses are presented:

\section{Hypothesis 1}

Employees being female is positively related to customer satisfaction.

\section{Hypothesis 2}

The age group of employees is positively related to customer satisfaction.

According to survey results, level of service is a factor that significantly influences consumer satisfaction in retail stores. This quality is positively associated with customer loyalty [19]. Numerous studies have attempted to shed light on the relationship between service attitude and customer satisfaction. According to [20], the importance of employee attitudes to service and the level of satisfaction with service vary significantly among customers of different nationalities in the tourism industry.

Based on a survey conducted by a research firm [12], $67.8 \%$ of Japanese supermarket customers (171 respondents, consisting of men and women of 59 years from 15 years in the Fukuoka area, western Japan were sampled for this research) agreed that employee attitude at the checkout is an important attribute of the shopping experience. In addition, $30.4 \%$ respondents agreed that the attitude of a checkout lane employee can make a negative impact in terms of the loyalty to this supermarket store.

In addition to consumers, store managers, human resource personnel, and stakeholders of the store acknowledged a positive impact on customer satisfaction from a positive customer service attitude shown by employees.

On this basis, the following hypothesis is presented:

\section{Hypothesis 3}

Good attitude by the employee at the checkout is positively related to customer satisfaction.

At supermarkets and other grocery stores in Japan, one of the services known to the customer is bagging; the clerk puts groceries into a shopping bag and then into the shopping cart. For example, in a convenience store, one of the most important responsibilities of the clerk in charge of the cash register is the bagging service.

Some baggers will put the items in the bag unless the customer refuses. The interviews indicated that consumers include the quality of the bagging service at the cash register in their evaluation. In addition, several people in management evaluate bagging as a service to the consumer business. That is, bagging can be considered as a factor that affects the consumer's evaluation.

On this basis, the following hypothesis is presented:

\section{Hypothesis 4}

Providing a bagging service is positively related to customer satisfaction.
In general, purchase intentions of consumers are affected by expected waiting time and unexpected delays.

An empirical test of the model with delayed airline passengers reveals that delays do affect service evaluations [21]. These studies demonstrate that actual waiting time, perceived waiting time, and the discontinuity between expected waiting time and perceived waiting time are related to satisfaction with the waiting experience [22]. For customers, waiting time is often a substitute for cost [1], [23].

Based on these studies, the following hypothesis is presented:

\section{Hypothesis 5}

Expected waiting time has a negative impact on customer satisfaction.

Consumers can be segmented according to several characteristics such as demographic factors.

Gender affects service quality perceptions and the relative importance attached to various service quality dimensions of hotels [24]. Furthermore, customers differ in satisfaction judgments, in that men put more emphasis on core service provision, while women value the relationship with the service staff [25].

A synthesis of ideas from these studies suggests hypotheses regarding the factors that should be most influential to male and female consumers in determining customer satisfaction with service encounters.

On this basis, the following hypothesis is presented:

\section{Hypothesis 6}

Differences in customer demographics (male or female) affect the importance of attributes at checkout.

These hypotheses are summarized as follows (Fig. 1).

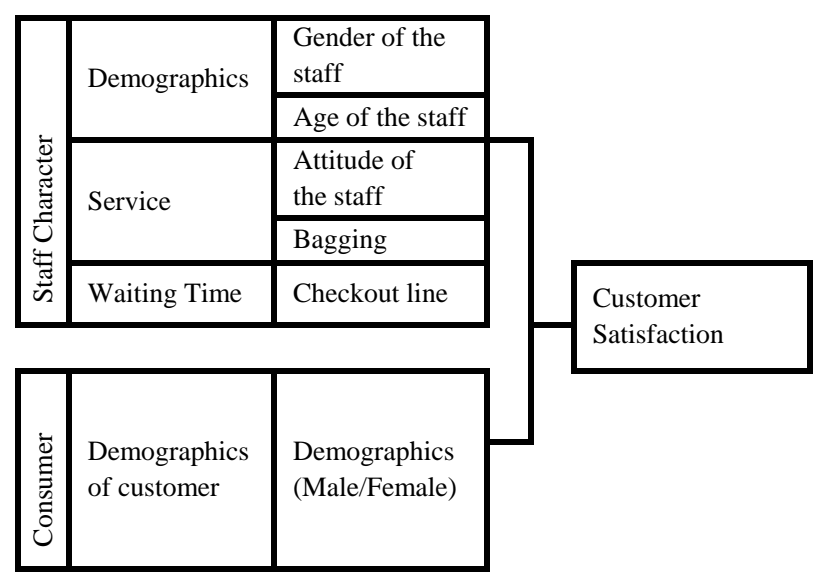

Fig. 1. Conceptual models of customer satisfactions of checkout service.

\section{Methodology}

\section{A. Methodology}

In this study, full-profile-rating conjoint analysis was used to estimate the relative importance of selected service characteristics on consumer preferences of checkout services. This method can systematically develop an effective product and service concept by considering consumer preferences and choices [26], [27]. It is possible to separately measure the importance of the factors for each [27], [28]. 
In this study, five features characteristic of the checkout service were analyzed. These features include 1) gender of the staff, 2) age of the staff, 3) attitude of the staff, 4) bagging service, and 5) checkout line. In addition, specifications for each attribute are provided. In conjoint analysis, these different attributes are called levels. The checkout service attributes and their levels tested in this analysis are summarized in Fig. 2.

\section{1) Gender of the staff attribute}

The gender of the staff attribute features two specifications: male staff and female staff.

\section{2) Age of the staff attribute}

The age of the staff attribute features two specifications: junior group (under 40) and middle/senior group (above 40).

\section{3) Attitude of the staff attribute}

Service level features two specifications: well-trained and untrained attitude.

\section{4) Bagging service attribute}

Bagging service features two specifications: no bagging and with bagging service by the checkout staff.

\section{5) Waiting time attribute}

The waiting time attribute specifications denote the number of persons waiting: one person, two people, and three people, corresponding to short, medium, and long waiting times, respectively.

\begin{tabular}{|c|c|c|c|}
\hline \multirow{2}{*}{ Attribute of the service } & \multicolumn{3}{|c|}{ Level } \\
\cline { 2 - 4 } & Level 1 & Level 2 & Level 3 \\
\hline Gender of the staff & Male & Female & - \\
\hline Age of the staff & $\begin{array}{c}\text { Junior } \\
\text { (Under 40) }\end{array}$ & $\begin{array}{c}\text { Middle or } \\
\text { Senior } \\
\text { (Above 40) }\end{array}$ & - \\
\hline Attitude of the staff & Untrained & Well-trained & - \\
\hline Bagging Service & No & Yes & 3 persons \\
\hline $\begin{array}{c}\text { Checkout line } \\
\text { (number of customers } \\
\text { already in line) }\end{array}$ & 1 person & 2 persons & \\
\hline
\end{tabular}

Fig. 2. Attribute and levels of checkout service.

\section{B. Combinations of Plancards}

Considering the above factors, there were $48(2 \times 2 \times 2 \times 2$ $\times 3$ ) possible combinations, or profiles, of checkout lines in the survey. Because 48 different choices are significantly large for a respondent, the number of choices to ten using factorial design was reduced (Fig. 3).

A respondent typically received ten conjoint cards depending on the number of factors and levels in the design. Each respondent was asked the following question:

"Imagine that you are considering going to the supermarket checkout line. The checkout line will include five features. Please read each description carefully. You will be asked to indicate how likely you would be to go to the line based on the five features presented." After they read the descriptions, they were asked, "Please indicate how likely you would be to stand in this checkout line."

The respondent was asked to rate each design on a 5-point scale that ranged from "Would stand in this checkout line" to "Would not stand in this checkout line" (Fig. 4).

\begin{tabular}{|c|l|c|c|c|c|}
\hline Card No. & $\begin{array}{c}\text { Gender of } \\
\text { the staff }\end{array}$ & $\begin{array}{c}\text { Age of } \\
\text { the staff }\end{array}$ & $\begin{array}{c}\text { Attitude of } \\
\text { the staff }\end{array}$ & $\begin{array}{c}\text { Bagging } \\
\text { Service }\end{array}$ & $\begin{array}{c}\text { Checkout } \\
\text { line }\end{array}$ \\
\hline 1 & Female & $\begin{array}{c}\text { Middle or } \\
\text { Senior }\end{array}$ & Untrained & No & 3 \\
\hline 2 & Male & Junior & Untrained & No & 1 \\
\hline 3 & Male & $\begin{array}{c}\text { Middle or } \\
\text { Senior }\end{array}$ & Well-trained & No & 1 \\
\hline 4 & Female & Junior & Well-trained & No & 2 \\
\hline 5 & Male & $\begin{array}{c}\text { Middle or } \\
\text { Senior }\end{array}$ & Untrained & Yes & 2 \\
\hline 6 & Female & Junior & Untrained & Yes & 1 \\
\hline 7 & Male & Junior & Well-trained & Yes & 3 \\
\hline 8 & Female & $\begin{array}{c}\text { Middle or } \\
\text { Senior }\end{array}$ & Well-trained & Yes & 1 \\
\hline 9 & Male & Junior & Well-trained & Yes & 1 \\
\hline 10 & Male & Junior & Well-trained & No & 2 \\
\hline \multicolumn{7}{|c|}{ Fig. 3. Combination of the question. } \\
\end{tabular}

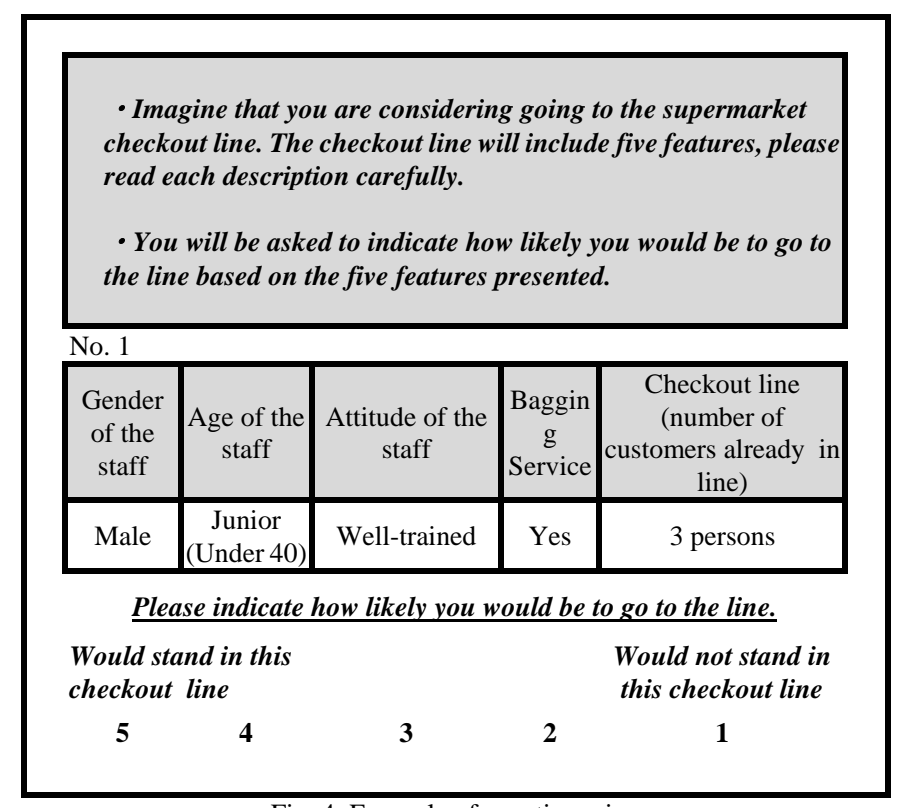

Fig. 4. Example of questionnaire.

\section{DATA}

A customer survey on supermarket checkout services was conducted over a period of two weeks ending on June 10, 2013. The survey area included four Japanese prefectures: Tokyo, Kanagawa, Chiba, and Saitama. These constitute the regions that comprise the so-called metropolitan area. The format of the questionnaire was a web-based survey.

The contents of the questionnaire were as follows. First, respondents were asked about their demographic variables, including gender, age, and residential area. In addition, they were presented a list combining the attributes of the cash register. The cash registers were evaluated on a 5-point scale.

The total number of respondents was 1,117. A sample of 415 respondents was used because these respondents entirely answered the survey. Of these, $39.2 \%$ were male $(N=163)$, and $60.7 \%$ were female $(N=252)$.

\section{CONCEPTUAL MOdEls AND ANALYSIS}

The following consumer behavior model for analysis was constructed: 


$$
\begin{gathered}
\text { Utility }=\left\{\begin{array}{l}
b_{\text {Male }}^{\text {Gender }} \times \text { Male } \\
b_{\text {Female }}^{\text {Gender }} \times \text { Female }
\end{array}+\left\{\begin{array}{l}
b_{\text {Junior }}^{\text {Age }} \times \text { Junior } \\
b_{\text {Middle.Senior }}^{\text {Age }} \times \text { Middle, Senior }
\end{array}\right.\right. \\
+\left\{\begin{array}{l}
b_{\text {Untrained }}^{\text {Atitude }} \times \text { Untrained } \\
b_{\text {Welltrainal }}^{\text {Attitu }} \times \text { Welltrained }
\end{array}+\left\{\begin{array}{l}
b_{\text {Yes }}^{\text {Baging }} \times \text { Yes } \\
b_{N o}^{\text {Bagging }} \times N o
\end{array}+\left\{\begin{array}{l}
b_{\text {one }}^{\text {Wait }} \times \text { one } \\
b_{\text {two }}^{\text {Wait }} \times \text { two } \\
b_{\text {three }}^{\text {Wait }} \times \text { three }
\end{array}\right.\right.\right.
\end{gathered}
$$

If a customer makes a selection of a go-to line, it is assumed that at that time the customer will try to maximize the utility in the feature options chosen. In this model, Utility is the dependent variable representing the customer's utility function. In the conjoint analysis, utility is divided into goods to derive "attribute"; it is assumed that the utility of each attribute can be defined, calculating total utility as the sum.

Next, Gender (male/female), Age (junior/senior), Attitude (untrained/well-trained), Bagging (yes/no), and Wait (one/two/three) represent attributes that affect a customer's utility, and $b_{\text {Male }}^{\text {Gender }}$ and $b_{\text {Female }}^{\text {Gender }}, b_{\text {Junior }}^{\text {Age }}$ and $b_{\text {Middle-Senior }}^{\text {Age }}, b_{\text {Untrained }}^{\text {Attitude }}$ and $b_{\text {Welltrainal }}^{\text {Attitude }}, b_{\text {Yes }}^{\text {Bagging }}$ and $b_{N o}^{\text {Bagging }}, b_{\text {one }}^{\text {Wait }}$ and $b_{\text {two }}^{\text {Wait }}$ or $b_{\text {three }}^{\text {Wait denote the }}$ coefficient estimates for each attribute. Gender denotes the gender of the staff (male/female) attribute. Age denotes the age group of the staff (junior, below 40/middle and senior, above 40) attribute. Attitude denotes the attitude of the staff (untrained/well-trained) attribute. Bagging denotes the bagging service (staff bags/self-service) attribute. Wait denotes the expected wait time for customer (number of

\begin{tabular}{|c|c|c|c|}
\hline \multirow{2}{*}{ Attribute } & \multicolumn{3}{|c|}{ Estimation of the Utility } \\
\hline & Level & Utility & $\begin{array}{c}\text { Standard } \\
\text { Deviation }\end{array}$ \\
\hline \multirow{2}{*}{ Gender } & Male & -0.078 & 0.041 \\
\hline & Female & 0.078 & 0.041 \\
\hline \multirow[b]{2}{*}{ Age } & Junior & 0.002 & 0.041 \\
\hline & $\begin{array}{l}\text { Middle or } \\
\text { Senior }\end{array}$ & -0.002 & 0.041 \\
\hline \multirow{2}{*}{ Attitude } & Untrained & -0.388 & 0.041 \\
\hline & Well-trained & 0.388 & 0.041 \\
\hline \multirow{2}{*}{ Bagging Service } & No & 0.020 & 0.041 \\
\hline & Yes & -0.020 & 0.041 \\
\hline \multirow{3}{*}{ Checkout line } & 1 person & 0.575 & 0.055 \\
\hline & 2 persons & 0.212 & 0.064 \\
\hline & 3 persons & -0.788 & 0.064 \\
\hline Constants & - & 3.435 & 0.043 \\
\hline Pearson's R & 0.998 & Significance & 0.000 \\
\hline Kendall's Tau & 0.982 & Significance & 0.000 \\
\hline
\end{tabular}
customers already in line) attribute.

The model was evaluated using SPSS Conjoint version 19. Tables I, II, and III show the calculation results. In addition, the calculated utility to calculate Averaged Importance for each attribute was used. In the group to be investigated, Averaged Importance is an index that shows the most important attribute within five attributes.

\begin{tabular}{|c|c|c|c|}
\hline \multirow[b]{2}{*}{ Attribute } & \multicolumn{3}{|c|}{ Estimation of the Utility } \\
\hline & Level & Utility & $\begin{array}{c}\text { Standard } \\
\text { Deviation }\end{array}$ \\
\hline \multirow{2}{*}{ Gender } & Male & -0.111 & 0.049 \\
\hline & Female & 0.111 & 0.049 \\
\hline \multirow[b]{2}{*}{ Age } & Junior & 0.018 & 0.049 \\
\hline & $\begin{array}{l}\text { Middle or } \\
\text { Senior }\end{array}$ & -0.018 & 0.049 \\
\hline \multirow{2}{*}{ Attitude } & Untrained & -0.339 & 0.049 \\
\hline & Well-trained & 0.339 & 0.049 \\
\hline \multirow{2}{*}{ Bagging Service } & No & 0.004 & 0.049 \\
\hline & Yes & -0.004 & 0.049 \\
\hline \multirow{3}{*}{ Checkout line } & 1 person & 0.531 & 0.067 \\
\hline & 2 person & 0.190 & 0.078 \\
\hline & 3 person & -0.721 & 0.078 \\
\hline Constants & - & 3.411 & 0.053 \\
\hline Pearson's R & 0.997 & Significance & 0.000 \\
\hline Kendall's Tau & 1.000 & Significance & 0.000 \\
\hline
\end{tabular}

TABLE II: EMPIRICAL RESULTS OF MALE RESPONDENTS $(N=163)$

Averaged Importance is expressed as a percent summing to $100 \%$ [28]. Each Averaged Importance is calculated as follows:

$$
I_{i}=\frac{B_{i}}{\sum_{i=1}^{5} B i} \times 100
$$

In this model, $I_{i}$ is the Averaged Importance of $i$ 's attribute, and $B_{i}$ is the range of the value of the utility of $i$ 's factors. These results are displayed in Fig. 5, 6, and 7.

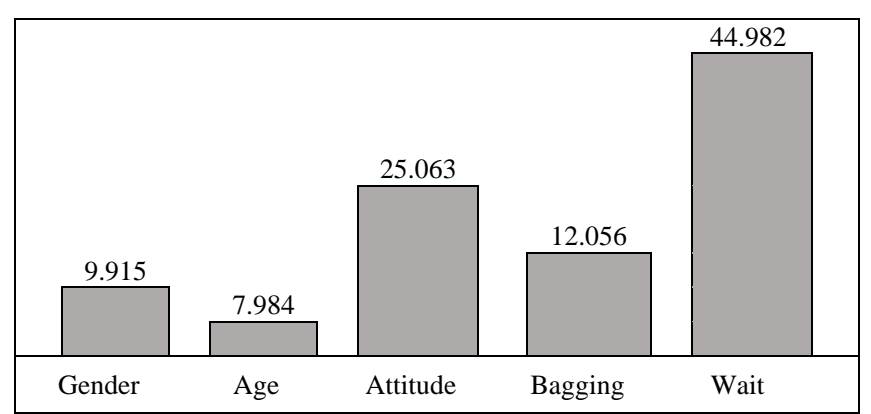

Fig. 5. Summary of importance (All respondents, $N=415$ ).

\section{EMPIRICAL RESULTS}

This section discusses the empirical results and findings. Empirical results for all respondents are as follows (Table I).

First, the conjoint model is investigated to clarify whether it corresponds to the data. Pearson's R shows the correlation coefficient between the predicted value by the conjoint model and evaluation scores of the respondents. If this value is close to 1 , it is seen to be a high correlation coefficient. In this model, Pearson's R is high (0.998). Kendall's tau indicates the reliability of the calculation result of the partial utility values. Because of its high value (0.982), the model of conjoint analysis is consistent with the response tendency of 
the respondents. Both Pearson's R and Kendall's tau relate to the significance level of the test for the lack of correlation. Both appear to be significant (sig. $<0.000$ ), indicating that the model is significant.

Second, the impact of demographic elements of the employee on the utility of the consumer is examined. The results showed that "male" has a negative effect $(-0.078)$, while "female" has a positive effect on utility value of consumers (+0.078). These results support Hypothesis 1 . However, the effect of gender on utility is relatively small (see Fig.5); this fact is evident from the fact that the Averaged Importance of this element to utility is the second smallest (9.915). Therefore, the gender of the cash register personnel does not have an important impact on the utility of consumers.

Next, the effect of age of the register personnel on the utility of the consumer is examined. Level Junior has a positive effect on customer's utility (0.002), while Middle or Senior gives a negative impact. These results reject Hypothesis 2. Also, the level of any impact on utility is small; the Averaged Importance is the smallest among the factors (7.984).

Third, the effect of the attribute of attitude of the staff on the utility of the consumer is considered. "Well-trained" has a 0.388 impact on the utility of the consumer, whereas "untrained" (i.e., low-level attitude) has a negative impact $(-0.388)$. These results support Hypothesis 3. Given that the Averaged Importance is 25.063 , this is second in the effect on the customer's utility.

Fourth, the effect of the Bagging service attribute is examined. The impact on the utility value is 0.020 . Interestingly, if the employee performs bagging, this acts against the negative utility value $(-0.020)$. On the other hand, if the consumer performs this as self-service, it appears that the utility value applied is positive (0.020). Thus, this finding rejects Hypothesis 4. This attribute's Averaged Importance to utility is 12.056. This is third in the effect on customer's utility.

Fifth, the effect of waiting time on utility is examined. The impact of latency on the consumer is important. When one person is waiting, the effect on utility is positive (0.575). A queue of two people has a value of 0.212 . Three people waiting has a negative impact $(-0.788)$. Overall, the Averaged Importance of this factor is 44.982; this attribute has the greatest degree of importance. This finding supports Hypothesis 5 and previous literature [29], which is anecdotally based.

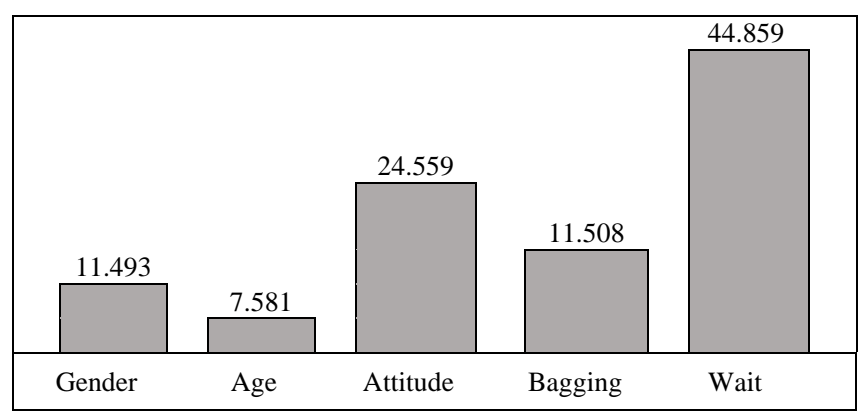

Fig. 6. Summary of importance (Male respondents, $N=163$ ).

Finally, the empirical results of male and female respondents are examined (Table II and Table III, Fig. 6 and Fig. 7). Although the results show that female respondents were more likely to choose older stuff, the order of the importance is the same. Therefore, differences in demographics do not have a significant effect on the differences in consumer preferences. This finding rejects Hypothesis 6.

The present findings do not support the findings of many previous studies [30], which state that female customers are in certain ways different from male customers in their perception of service.

\begin{tabular}{|c|c|c|c|}
\hline \multirow[b]{2}{*}{ Attribute } & \multicolumn{3}{|c|}{ Estimation of the Utility } \\
\hline & Level & Utility & $\begin{array}{c}\text { Standard } \\
\text { Deviation }\end{array}$ \\
\hline \multirow{2}{*}{ Gender } & Male & -0.056 & 0.035 \\
\hline & Female & 0.056 & 0.035 \\
\hline \multirow{2}{*}{ Age } & Junior & -0.007 & 0.035 \\
\hline & $\begin{array}{l}\text { Middle or } \\
\text { Senior }\end{array}$ & 0.007 & 0.035 \\
\hline \multirow{2}{*}{ Attitude } & Untrained & -0.419 & 0.035 \\
\hline & Well-trained & 0.419 & 0.035 \\
\hline \multirow{2}{*}{ Bagging Service } & No & 0.030 & 0.035 \\
\hline & Yes & -0.030 & 0.035 \\
\hline \multirow{3}{*}{ Checkout line } & 1 person & 0.604 & 0.047 \\
\hline & 2 person & 0.227 & 0.055 \\
\hline & 3 person & -0.831 & 0.055 \\
\hline Constants & - & 3.449 & 0.037 \\
\hline Pearson's R & 0.999 & Significance & 0.000 \\
\hline Kendall's Tau & 0.929 & Significance & 0.000 \\
\hline
\end{tabular}

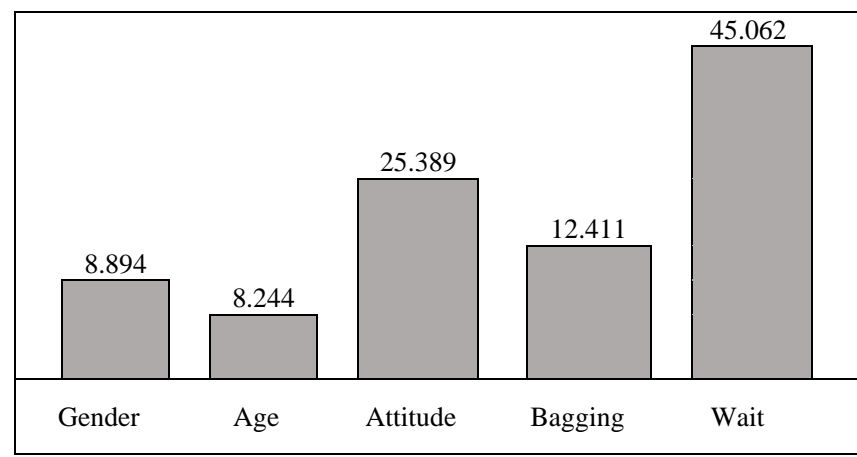

Fig. 7. Summary of importance (Female respondents, $N=252$ ).

\section{DISCUSSION}

First, the analysis shows that the attributes of employees' demographics, i.e., gender and age, have little effect on customer satisfaction. This result is different from the present hypothesis and from previous research. Although female frontline service staff still dominate checkout service staffing, it appears that there is little consumer interest in this factor in the grocery industry. Based on these findings, the person in charge of employee placement and hiring in supermarkets may not need to give special consideration to personal attributes of employees.

Second, the influence factor of staff attitudes has a high 
effect on customer satisfaction. This finding is consistent with the present pilot survey and previous studies. Although supermarkets have an image that it incorporates discounting, low costs, and self-service, it is necessary to focus on training frontline employees to have an appropriate service attitude.

Third, in opposition to the present hypothesis, bagging services have a negative impact on customer satisfaction, while customers performing their own bagging have a positive effect on the customer utility. This may be because of the following: in a supermarket checkout situation, a customer's priority is to reduce the waiting time; they may feel that this service results in an increase in waiting time.

Fourth, the focus is on the influence of the number of waiting persons. This factor has one of the most significant influences on the utility of consumers. In particular, when more than three people are already waiting, the negative impact on the utility of consumers is very large. This finding supports the anecdotal report that claims that, once a wait lasts longer than $3 \mathrm{~min}$, the perceived waiting time multiplies with each passing minute [29]. The report says that shoppers who actually waited for $5 \mathrm{~min}$ told surveyors that they felt they had waited twice as long.

For a manager, it is necessary to make efforts to reduce this waiting time or perform various tricks on customers, such as offering opportunities for impulse buying (e.g., items such as tiny stuffed animals and gift cards next to lines to distract them from the wait [29]).

\section{CONCLUSION}

Increasing customer satisfaction is an important task in academia, but it is also desirable in marketing. Register service is received by the customers at the final step in the retail process. Customer perception of service levels are likely to be directly linked to revenues for the retail store. Although there are numerous studies on service attitude and customer satisfaction, they do not specifically address checkout customers.

This study conducted a questionnaire survey on checkout services for supermarkets in and around the Tokyo metropolitan area. Then, using conjoint analysis, the factors in checkout services to which consumers attach importance are analyzed.

The conclusions are as follows. The amount of anticipated waiting time is the most influential factor in consumer satisfaction; in particular, a queue of three or more was found to significantly reduce consumer satisfaction. A good employee attitude is also important to customers. Furthermore, an interesting result is derived, one counter to conventional theory: the gender and age of an employee have little effect on consumer satisfaction. As for bagging services, these might have a negative impact on consumer satisfaction. These results not only give new implications for research but also are useful in practical terms, such as to guide improvements in the operation of retail stores.

Limitations of this study are as follows. The study area and the sample size are limited; it is necessary to consider a wider range of demographic factors. Furthermore, it is necessary to study whether similar results are obtained in non-supermarket settings, such as service retailers.

\section{ACKNOWLEDGMENT}

The author would like to express his gratitude for the assistance and useful information provided by many companies and individuals involved with human resources, and to consumers for their responses to the interviews and survey.

\section{REFERENCES}

[1] M. M. Davis and M. J. Maggard, "An analysis of customer satisfaction with waiting times in a two-stage service process," J. Oper. Manag., vol. 9, no. 3, pp. 324-334, Aug. 1990.

[2] S. A. Taylor and T. L. Baker, "An assessment of the relationship between service quality and customer satisfaction in the formation of consumers' purchase intentions," J. Retailing, vol. 70, no. 2, pp. 163-178, Summer 1994.

[3] G. S. Sureshchandar, C. Rajendran, and R. N. Anantharaman, "The relationship between service quality and customer satisfaction-a factor specific approach," J. Serv. Marketing, vol. 16, no. 4, pp. 363-379, 2002.

[4] H.-H. Hu, J. Kandampully, and T. D. Juwaheer, "Relationships and impacts of service quality, perceived value, customer satisfaction, and image: an empirical study," Serv. Ind. J., vol. 29, no. 2, pp. 111-125, Feb. 2009

[5] M. D. Hartline and K. C. Jones, "Employee performance cues in a hotel service environment: Influence on perceived service quality, value, and word-of-mouth intentions," J. Bus. Res., vol. 35, no. 3, pp. 207-215, Mar. 1996.

[6] F. Saleh and C. Ryan, "Analysing service quality in the hospitality industry using the SERVQUAL model," Serv. Ind. J., vol. 11, no. 3, pp. 324-345, 1991.

[7] H. Oh, "Service quality, customer satisfaction, and customer value: A holistic perspective," Int. J. Hosp. Manag., vol. 18, no. 1, pp. 67-82, Mar. 1999.

[8] R. Vázquez, I. A. Rodríguez-Del Bosque, A. M. Díaz, and A. V. Ruiz, "Service quality in supermarket retailing: identifying critical service experiences," J. Retailing Consum. Serv., vol. 8, no. 1, pp. 1-14, January 2001.

[9] M. L. Meuter, A. L. Ostrom, R. I. Roundtree, and M. J. Bitner, "Self-service technologies: Understanding customer satisfaction with technology-based service encounters," J. Marketing, vol. 64, no. 3, pp. 50-64, July 2000.

[10] J. J. Turner and K. Borch, "Wham, bam, thank you scan: An analysis of customer satisfaction with self-scan checkouts in IKEA, Germany," $J$. Marketing Retail, vol. 1, pp. 6-16, 2012.

[11] Do House Co., Ltd. (2012). Questionnaire investigation: Questionnaire survey on self-checkout user. [Online]. Available: http://www.dohouse.co.jp/news/research/20120725/

[12] GCOM Co, Ltd. (2006). Questionnaire about the image of the supermarket. [Online]. Available: http://www.gcom-net.co.jp/report/rep0608.pdf

[13] C. Mathies and M. Burford, "Gender differences in the customer service understanding of frontline employees," Working papers, Univ. New South Wales, 2009.

[14] B. J. Babin and J. S. Boles, "Employee behavior in a service environment: A model and test of potential differences between men and women," J. Marketing, vol. 62, no. 2, pp. 77-91, 1998.

[15] R. D. Mascio, "The service models of frontline employees," $J$. Marketing, vol. 74, no. 4, pp. 63-80, 2010.

[16] L. L. Bove and D. A. Smith, "Relationship strength between a customer and service worker -- Does gender dyad matter?" Serv. Marketing Quarterly, vol. 27, no. 3, pp. 17-34, 2006.

[17] R. L. Snipes, N. F. Thomson, and S. L. Oswald, "Gender bias in customer evaluations of service quality: An empirical investigation," $J$. Serv. Marketing, vol. 20, no. 4, pp. 274-284, 2006.

[18] C. T. Kulik and R. L. Jr. Holbrook, "Demographics in service encounters: Effects of racial and gender congruence on perceived fairness," Social Justice Res., vol. 13, no. 4, pp. 375-402, December 2000.

[19] A. Wong and A. Sohal, "Service quality and customer loyalty perspectives on two levels of retail relationships," J. Serv. Marketing, vol. 17, no. 5, pp. 495-513, 2003.

[20] C.-M. Kuo, "The importance of hotel employee service attitude and the satisfaction of international tourists," Serv. Ind. J., vol. 27, no. 8, 2007. 
[21] S. Taylor, "Waiting for service: The relationship between delays and evaluations of service," J. Marketing, vol. 58, no. 2, pp. 56-69, Apr. 1994.

[22] M. M. Davis and J. Heineke, "How disconfirmation, perception and actual waiting times impact customer satisfaction," Int. J. Serv. Ind. Manag., vol. 9, no. 1, pp. 64-73, 1998.

[23] M. S. Sridhar, "Waiting lines and customer satisfaction," SRELS J. Inf. Manag., vol. 38, no. 2, pp. 99-112, 2001

[24] T. D. Juwaheer, "Gender bias in hotel guests' perceptions of service quality: An empirical investigation of hotels in Mauritius," e-Rev. Tourism Res., vol. 9, no. 5, pp. 164-189, 2011.

[25] D. Iacobucci and A. Ostrom, "Gender differences in the impact of core and relational aspects of services on the evaluation of service encounters," J. Consum. Psych., vol. 2, no. 3, pp. 257-286, 1993.

[26] H. Asano, An Introduction to Multivariable Analysis (Nyuumonn Tahennryoukaiseki no Jissai), $2^{\text {nd }}$ ed. Kodansha Publishing, 2000.

[27] T. Sanagi, SPSS Conjoint Analysis Manual (SPSS ni yoru Konnjoinnto Bunnseki), Tokyo Tosho Publishing, 2001.

[28] S. Okamoto, Conjoint Analysis (Konnjoinnto Bunnseki), Nakanishiya Publishing, 1999.

[29] R. A. Smith, "Find the best checkout line," Wall Street Journal, December 8, 2011.

[30] F. Alamdari and J. Burrell, "Marketing to female business travellers," $J$. Air Transport, World Wide, vol. 5, no. 2, pp. 3-18, 2000.

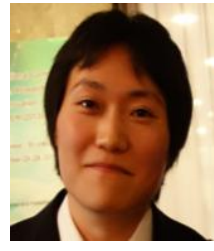

Mitsunori Hirogaki was born in Kyoto City, Japan, on July 14, 1978. In 2008, he received his Ph.D. in commercial science from Kobe University, Japan. He was a full-time lecturer from 2007 to 2010 and an associate professor from 2010 to 2013 at Hiroshima University of Economics, Hiroshima Prefecture, Japan. Since 2013, he has been an associate professor at Kushiro Public University of Economics, Hokkaido, Japan.

His work has appeared in journals such as International Review of Retailing, Distribution and Consumer Research, the International Journal of Management Cases, and International Journal of Innovation, Management and Technology. His current research interest is marketing strategies to the mature market, including consumer behavior, e-commerce, and supply chain management. Dr. Hirogaki is a member of the Japan Society of Marketing and Distribution, the Japan Association for Consumer Studies, and the Japanese Economic Association.

Since 2013, he has worked as a member of the governing committee in the non-profit organization "NAGOMI." In the organization, he has been engaged to provide retail services with high sustainability to food desserts, with market survey and the development of retail format in Kushiro City, Hokkaido. 